\title{
AUDIT FORECAST ATAS GROSS DOMESTIC PRODUCTS 2016 SEBAGAI PENGARUH DARI PERTUMBUHAN PEMBIAYAAN DAN ASET WUJUD KESIAPAN MASYARAKAT EKONOMI ASEAN
}

\author{
Ika Wahyuni, \\ Mahasiswa Program Doktor \\ Universitas Trisakti, Jakarta, Indonesia \\ dan \\ M. Nuryatno Amin \\ Dosen Universitas Trisakti, Jakarta, Indonesia
}

\begin{abstract}
As a country facing global challenges, a country will be declared ready when a country experiences domestic growth measured through gross domestic product (GDP). Welcoming the ASEAN economic community 2017, of course the role of growth will show the readiness of society as a whole. In this study, the authors will predict the calculation of GDP based on the influence of the growth of bank financing. In the GDP banking is an indicator of economic growth which is an important measure in explaining the economic performance which is directly the performance of economic actors providing goods and services including the banking industry. Economic growth can increase the cash flow of banks by increasing demand for financing by companies and households. During periods of strong economic growth, financing demand tended to increase. Because financing tends to generate better returns

Keywords: Gross Domestic Product (GDP); Forecasting; Growth; Financing; $M E A$
\end{abstract}

\begin{abstract}
Abstraks: Sebagai suatu negara yang menghadapi tantangan global, maka suatu negara akan dinyatakan siap ketika suatu negara mengalami pertumbuhan dalam negeri yang diukur melalui gross domestic product (GDP). Menyambut masyarakat ekonomi Asean 2017, sudah tentu peran dari pertumbuhan akan menunjukkan kesiapan masyarakat secara menyeluruh. Dalam penelitian ini, penulis akan meramalkan perhitungan dari GDP berdasarkan pengaruh dari pertumbuhan pembiayaan perbankan. Di dalam perbankan GDP adalah indikator dari pertumbuhan ekonomi yang merupakan ukuran penting dalam menjelaskan kinerja ekonomi yang secara langsung merupakan kinerja dari pelaku ekonomi yang menyediakan barang dan jasa termasuk industri perbankan. Pertumbuhan ekonomi dapat meningkatkan cash flow bank dengan cara meningkatkan permintaan pembiayaan oleh perusahaan dan rumah tangga. Selama periode pertumbuhan ekonomi yang kuat permintaan pembiayaan cenderung meningkat. Karena pembiayaan cederung menghasilkan keuntungan lebih baik.
\end{abstract}

Kata Kunci: Gross Domestic Product(GDP); Peramalan; Pertumbuhan; Pembiayaan; MEA 


\section{Pendahuluan}

Kesiapan suatu negara menghadapi pasar bebas dan masyarakat ekonomi ASEAN di tahun 2017 pada khususnya di Indonesia, dapat ditunjukkan melalui pertumbuhan Gross domestic product (GDP). GDP sendiri digunakan untuk mengukur semua barang dan jasa yang dihasilkan oleh suatu negara dalam periode tertentu. Komponen yang ada dalam GDP yaitu pendapatan, pengeluaran/investasi, pengeluaran pemerintah dan selisih ekspor - import. Stiglitz dan Walsh (2006) menjelaskan bahwa GDP menyediakan penilaian terbaik untuk mengukur tingkat produksi. Akan tetapi perubahan sifat dasar produksi dari bentuk pertumbuhan dalam underground economy menjadi bentuk inovasi teknologi baru bisa memengaruhi kemampuan GDP untuk menyediakan gambaran yang akurat mengenai kinerja ekonomi. Lebih jauh GDP menggambarkan keseluruhan tingkat aktivitas ekonomi dalam sebuah negara, yaitu jumlah barang dan jasa yang diproduksi untuk sebuah pasar.

Hal itu menunjukkan bahwa GDP adalah indikator dari pertumbuhan ekonomi yang merupakan ukuran penting dalam menjelaskan kinerja ekonomi yang secara langsung merupakan kinerja dari pelaku ekonomi yang menyediakan barang dan jasa termasuk industri perbankan. Sebagai wujud indikasi petumbuhan dari masyarakat, maka siklus pembiayaan dalam usaha perbankan akan semakin besar, dan hal tersebut menunjukkan kemampuan daya beli dan kesejahteraan masyarakat yang berangsur meningkat, dan dapat dinyatakan sebagai salah satu indikasi kesiapan masayarakat dalam ekonomi ASEAN 2016. Pertumbuhan ekonomi dapat meningkatkan cash flow bank dengan cara meningkatkan permintaan pembiayaan oleh perusahaan dan rumah tangga. Selama periode pertumbuhan ekonomi yang kuat permintaan pembiayaan cenderung meningkat. Karena pembiayaan cederung menghasilkan keuntungan lebih baik dari pada investasi surat-surat berharga, maka expected cash flow akan lebih tinggi. Alasan lain dari tingginya cash flow adalah semakin sedikit tingkat risiko default yang terjadi selama masa pertumbuhan ekonomi yang kuat (Madura, 2006).

\section{Landasan Teori}

Pertumbuhan atas GDP mempunyai dampak terhadap kualitas pinjaman yang diberikan oleh perbankkan. Lebih jauh dikemukakan bahwa apabila suatu perekonomian mengalami penurunan dalam arti pertumbuhan GDP negatif, maka hal ini akan berdampak pada memburuknya kualitas perbankan. Fenomena ini seperti tersebut diatas dapat dilihat ketika pada tahun 2008 Indonesia mengalami krisis ekonomi yang berdampak pada menurunnya kegiatan di sektor rill. GDP juga bisa diramalkan, oleh karena itu dibutuhkan suatu aktifitas permalan atas pertumbuhan ekonomi. Menurut Chung (2012:234) suatu aktivitas peramalan adalah suatu fungsi bisnis yang berusaha memperkirakan penjualan dan penggunaan produk sehingga produk itu dapat dibuat dalam kuantitas yang tepat. Dengan demikian, peramalan merupakan suatu dugaan terhadap permintaan yang akan datang berdasarkan pada beberapa variabel peramal, sering berdasarkan data deret waktu historis.

Peramalan adalah seni dan ilmu memprediksi peristiwa-peristiwa masa depan. Peramalan memerlukan pengambilan data histories dan memproyeksikannya ke masa depan dengan beberapa bentuk model matematis. Bisa jadi berupa prediksi subyektif atau intuitif tentang masa depan. Atau peramalan bisa mencakup kombinasi model matematis yang disesuaikan dengan penilaian yang baik oleh manajer. Peramalan biasanya dikelompokkan oleh horison waktu masa depan yang mendasarinya. Tiga kategori yang bermanfaat bagi manajer operasi adalah:

a. Peramalan jangka pendek, rentang waktunya mencapai satu tahun tetapi umumnya kurang dari tiga bulan. Peramalan jangka pendek digunakan untuk merencanakan pembelian, penjadwalan kerja, jumlah tenaga kerja, penugasan dan tingkat produksi.

b. Peramalan jangka menengah, peramalan jangka menengah biasanya berjangka tiga bulan hingga tiga tahun. Peramalan ini sangat bermanfaat dalam perencanaan penjualan, perencanaan dan penganggaran produksi, penganggaran kas, dan menganalisis berbagai rencana operasi. 
c. Peramalan jangka panjang, rentang waktunya biasanya tiga tahun atau lebih; digunakan dalam merencanakan produk baru, pengeluaran modal, lokasi fasilitas, atau ekspansi dan penelitian serta pengembangan.

\section{Metodologi Penelitian}

Gross Domestic Product yaitu total nilai uang dari semua barang dan jasa yang diproduksi dalam suatu perekonomian selama satu periode. Dalam penelitian ini variabel GDP yang digunakan adalah dalam bentuk pertumbuhan GDP riil Quarter on Quarter. Variabel ini dinotasikan dengan notasi GGDP yang diperoleh dengan rumus sebagai berikut:

$$
\mathrm{GDP}_{\mathrm{t}}=\frac{\mathrm{GDP}_{\mathrm{t}}-\mathrm{GDP}_{\mathrm{t}-1}}{\mathrm{GDP}_{\mathrm{t}-1}} \mathrm{X} 100 \%
$$

Metode analisis data yang digunakan dalam penelitian ini adalah dengan metode analisi Regresi Linier Berganda. Dalam melakukan analisis regresi linier berganda, metode ini mensyaratkan untuk melakukan uji asumsi klasik agar mendapatkan hasil regresi yang baik (Zharnowitz, 2013) berdsarkan peramalan GDP yang akan terjadi di tahun 2017. Dalam menganalisis model regresi linear berganda agar menghasilkan estimator yang baik, yaitu linier tidak bias dengan varian yang minimum (best linier unbiased estimator $=$ blue) adalah terpenuhinya asumsi asumsi dasar regresi yaitu dengan melakkukan serangkaian uji asumsi klasik.Terjadinya multikolinearitas disebabkan adanya saling korelasi antar variabel bebas itu sendiri, sehingga dalam hal ini sulit untuk diketahui variabel bebas mana yang mempengaruhi variabel tidak bebas. Gejala multikolinearitas dapat dilihat pada nilai VIF apabila $<10$ mengindikasikan bahwa dalam model tidak terjadi multikolinieritas, tetapi bila VIF $>10$, mengindikasikan bahwa dalam model terjadi multikolinieritas serius. Heterokedastisitas menunjukkan timbulnya gejala kesalahan varians gangguan yang menyebabkan tidak samanya probabilitas varians independen. Cara yang dapat dilakukan untuk mendeteksi ada tidaknya Heterokedastisitas menurut Crushore (2011: 9). Untuk dapat menyelesaikan permasalahan sekaligus membuktikan apakah hipotesis diterima atau ditolak di dalam dalam penelitian ini, maka digunakan alat analisis statistik regresi linear berganda. Menurut Rangkuti (2007: 23-25) formulasi regresi linear berganda adalah sebagai berikut:

$\mathrm{Y}=\mathrm{b}_{\mathrm{o}}+\mathrm{b}_{1} \mathrm{X}_{1}+\ldots+\mathrm{b}_{\mathrm{n}} \mathrm{X}_{\mathrm{n}}+\mathrm{e}$

Dimana:

$\mathrm{Y} \quad=$ Variabel dependen

$\mathrm{X} \quad=$ Variabel independen

bo $\quad=$ Konstanta

$\mathrm{b}_{1}-\mathrm{b}_{\mathrm{n}} \quad=$ Koefisien Regresi

e $\quad=$ Standar eror

Jika formulasi tersebut dimasukkan ke dalam penelitian ini, maka diperoleh persamaan regresi, sebagai berikut:

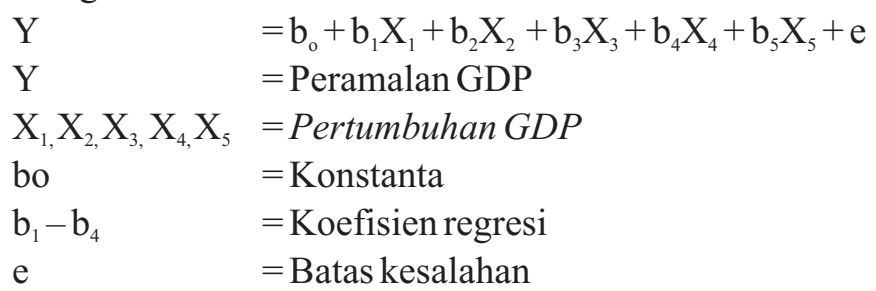

Kemudian untuk menguji keberartian dari koefisien regresi secara serempak, digunakan pengujian statistik uji F dengan formulasi sebagai berikut (Rangkuti, 2007: 27): 


$$
U j i F=\frac{R^{2} / k}{\left(1-R^{2}\right) /(n-k-1)}
$$

Dimana:

$\mathrm{F}=$ Diperoleh dari tabel distribusi $\mathrm{F}$

$\mathrm{R}^{2}=$ koefisien determinasi ganda

$\mathrm{k}=$ jumlah variabel independen

$\mathrm{n} \quad$ =jumlah sampel

Dengan kaidah pengambilan keputusan sebagai berikut:

a. Jika $\mathrm{F}_{\text {hitung }}>\mathrm{F}_{\text {tabel }}$ pada tingkat kepercayaan $95 \%(\alpha=0,05)$, maka terbukti bahwa peramalan GDP mampu terjadi berdasarkan pertumbuhannya. Dengan demikian hipotesis alternatif $\left(\mathrm{H}_{1}\right)$ diterima dan hipotesis mula-mula (Ho) ditolak.

b. Jika $\mathrm{F}_{\text {hitung }}<\mathrm{F}_{\text {tabel }}$ pada tingkat kepercayaan $95 \%(\alpha=0,05)$, maka terbukti bahwa kelima pertumbuhan secara nyata (signifikan), tidak mempengaruhi peramalan GDP mampu terjadi berdasarkan pertumbuhannya. Dengan demikian hipotesis alternatif $\left(\mathrm{H}_{1}\right)$ ditolak dan hipotesis mula-mula (Ho) diterima.

Dengan pengambilan keputusan sebagai berikut:

a. Jika $t_{\text {hitung }}>t_{\text {tabel }}$ pada tingkat kepercayaan 95\% $(\alpha=0,05)$, maka terbukti bahwa kelima pertumbuhan GDP mampu terjadi berdasarkan pertumbuhannya secara nyata (signifikan), mempengaruhi peramalan GDP di 2016.

b. Jika $t_{\text {hitung }}<t_{\text {tabel }}$ pada tingkat kepercayaan 95\% $(\alpha=0,05)$, maka terbukti bahwa kelima pertumbuhan GDP mampu terjadi berdasarkan pertumbuhannya secara nyata (signifikan), tidak mempengaruhi peramalan GDP di 2016.

Instrumen penelitian yang dianggap valid adalah suatu instrumen yang benar-benar mampu mengukur variabelnya. Uji validitas dilakukan untuk mengetahui apakah alat ukur yang telah disusun benar-benar mampu mengukur apa yang perlu diukur. Suatu alat ukur yang validitasnya tinggi akan mempunyai varian kesalahan yang kecil atau dengan kata lain test tersebut menjalankan ukurannya dengan memberikan hasil yang sesuai dengan maksud test tersebut. Untuk mengetahui apakah instrumen tersebut valid, maka digunakan uji validitas dengan menggunakan analisis kesahihan butir, dengan teknik korelasi pruduct moment atau yang biasa disebut momen tangkar. Masrun (Ogneva, 2012:70) mengatakan bilamana koefisien korelasi antar skor suatu indikator dengan skor total seluruh indikator adalah positif dan lebih besar $0,3(\mathrm{r} \geq 0,3)$ maka instrumen tersebut dianggap valid.

Uji keandalan dilakukan terhadap pertanyaan-pertanyaan yang sudah valid, guna mengetahui sejauh mana hasil pengukuran tetap konsisten bila dilakukan pengukuran kembali terhadap gejala yang sama. Dalam penelitian ini akan menggunakan konsistensi internal untuk mengukur reliabilitas alat ukur. Adapun metode perhitungan koefisien reliabilitas yang digunakan adalah metode Alpha Crobach. Setelah nilai koefisien diperoleh, maka perlu ditetapkan suatu nilai koefisien reliabilitas dianggap reliabel. Di mana disarankan bahwa koefisien reliabilitas antara 0,70 0,80 cukup baik untuk tujuan penelitian dasar (Kaplan et all, 2013: 126). Sedangkan menurut Malhotra (Ogneva, 2012:71) bahwa suatu instrumen dikatakan reliabel manakalah memenuhi standar koefisien alpha Cronbach lebih besar dari 0,6 $(\alpha \geq 0.6)$. 


\section{Hasil Dan Pembahasan}

Ogneva (2012:70) mengatakan bilamana koefisien korelasi antar skor suatu indikator dengan skor total seluruh indikator adalah positif dan lebih besar $0,3(\mathrm{r} \geq 0,3)$ maka instrumen tersebut dianggap valid. Sedangkan menurut Konchitchki (2011: 1078) bahwa instrumen dapat dikatakan valid manakalah $\mathrm{r}_{\text {hitung }}$ yang diperoleh lebih besar dari $\mathrm{r}_{\text {tabel. }}$ Dalam penelitian ini, rujukan yang dipakai untuk menentukan kesahihan setiap butir pertanyaan mengacu dengan pendapat Ogneva, dengan harapan semakin tinggi nilai batas syarat validitas diharapkan dapat memberikan keakuratan kuesioner dalam mengukur presepsi responden sehingga dapat pula memberikan kesimpulan penelitian apa adanya.

Tabel 4.1 Hasil Pengujian Validitas

\begin{tabular}{|l|r|r|r|r|r|}
\hline & $\begin{array}{c}\text { Scale Mean } \\
\text { if Item } \\
\text { Deleted }\end{array}$ & $\begin{array}{c}\text { Scale } \\
\text { Variance if } \\
\text { Item Deleted }\end{array}$ & $\begin{array}{c}\text { Corrected } \\
\text { Item-Total } \\
\text { Correlation }\end{array}$ & $\begin{array}{c}\text { Squared } \\
\text { Multiple } \\
\text { Correlation }\end{array}$ & $\begin{array}{c}\text { Cronbach's } \\
\text { Alpha if Item } \\
\text { Deleted }\end{array}$ \\
\hline X1.1 & 8,1700 & 2,062 &, 672 &, 455 &, 735 \\
X1.2 & 8,2700 & 2,200 &, 674 &, 456 &, 738 \\
\hline X2.1 & 8,6700 & 2,910 &, 640 &, 461 &, 612 \\
X2.2 & 8,8500 & 2,553 &, 648 &, 464 &, 598 \\
\hline X3.1 & 11,9100 & 3,376 &, 602 &, 396 &, 714 \\
X3.2 & 12,2900 & 4,006 &, 410 &, 191 &, 805 \\
\hline X4.1 & 6,1900 & 1,307 &, 384 &, 149 &, 639 \\
X4.2 & 6,4700 &, 918 &, 491 &, 255 &, 506 \\
\hline X5.1 & 12,0200 & 5,353 &, 843 &, 715 &, 869 \\
X5.2 & 12,2000 & 4,970 &, 853 &, 733 &, 865 \\
X5.3 & 12,1000 & 6,111 &, 775 &, 631 &, 898 \\
X5.4 & 11,8900 & 5,109 &, 756 &, 585 &, 904 \\
\hline Y1 & 12,0800 & 2,377 &, 634 &, 482 &, 733 \\
Y2 & 12,5100 & 2,818 &, 476 &, 272 &, 807 \\
\hline
\end{tabular}

Sumber : Olah data penulis 2017

Sebagaimana telah dijelaskan di atas bahwa untuk mengumpulkan data dalam penelitian ini digunakan kuesioner. Oleh karena kuesioner yang digunakan adalah kuesioner yang belum terukur tingkat konsistensi pertanyaannya, maka untuk mengukur tingkat konsistensi perlu dilakukan pengujian konsistensi atau yang lazim disebut uji reliabilitas. Malhotra (Ogneva, 2012: 71) mengatakan suatu instrumen dikatakan reliabel manakalah memenuhi standar koefisien alpha Cronbach lebih besar dari 0,6 $(\alpha \geq 0.6)$. Berdasarkan hasil pengujian reliabilitas keseluruhan variabel penelitian diketahui masing-masing variabel mempunyai alpha Cronbach sebagaimana berikut:

Tabel 4.2 Hasil Uji Reliabilitas

\begin{tabular}{|c|c|c|c|}
\hline & $\begin{array}{c}\text { Cronba } \\
\text { ch's } \\
\text { Alpha }\end{array}$ & $\begin{array}{c}\text { Cronbach's } \\
\text { Alpha Based } \\
\text { on } \\
\text { Standardized } \\
\text { Items }\end{array}$ & $\begin{array}{c}\text { Nof } \\
\text { Items }\end{array}$ \\
\hline X1 &, 813 &, 816 & 3 \\
\hline X2 &, 736 &, 749 & 4 \\
\hline X3 &, 778 &, 776 & 4 \\
\hline X4 &, 646 &, 647 & 3 \\
\hline X5 &, 911 &, 915 & 4 \\
\hline Y &, 796 &, 797 & 4 \\
\hline
\end{tabular}

Sumber : Olah data penulis 2017 
Merujuk dari pendapat Malhotra (Ogneva, 2012: 71) bahwa suatu instrumen dikatakan reliabel manakala memenuhi standar koefisien alpha Cronbach lebih besar dari 0,6 $(\alpha \geq 0.6)$ maka dapat dikatakan bahwa angka koefisien reliabilitas yang diperoleh sebagaimana pada Tabel 5.2 telah memenuhi syarat reliabilitas, dengan demikian kuesioner yang digunakan dalam penelitian ini cukup handal dalam mengukur persepsi responden terhadap variabel yang diteliti. Untuk mengetahui gejala multikolinearitas dapat dilihat pada nilai VIF apabila $<10$ mengindikasikan bahwa dalam model tidak terjadi multikolinieritas, tetapi bila VIF $>10$, mengindikasikan bahwa dalam model terjadi multikolinieritas serius. Dalam penelitian ini nilai VIF yang diperoleh $<10$ sehingga dapat dikatakan tidak terjadi multikolinearitas, dengan demikian analisis regresi dapat dilanjutkan.

Tabel 4.3 Collinearity Statistics

\begin{tabular}{|c|c|c|c|}
\hline \multirow{2}{*}{ No } & Varia & \multicolumn{2}{|c|}{ Collinearity Statistics } \\
\cline { 3 - 4 } & ble & Tolerance & VIF \\
\hline 1 & $\left(\mathrm{X}_{1}\right)$ &, 702 & 3,316 \\
2 & $\left(\mathrm{X}_{2}\right)$ &, 951 & 1,051 \\
3 & $\left(\mathrm{X}_{3}\right)$ &, 888 & 2,306 \\
4 & $\left(\mathrm{X}_{4}\right)$ &, 974 & 2,671 \\
5 & $\left(\mathrm{X}_{5}\right)$ &, 955 & 3,918 \\
\hline
\end{tabular}

Sumber : Olah data penulis 2017

Heterokedastisitas mampu untuk menunjukkan adanya gejala kesalahan varians gangguan yang menyebabkan tidak sama probabilitas varian gangguan untuk setiap pengamatan atas seluruh nilai variabel independen. Gejala heterokedastisitas secara sederhananya dapat dilihat dari tabel scatterplot di mana sebaran titik-titik yang terdapat dalam Tabel tersebut tidak membentuk pola yang sistematis. Selain itu dapat pula digunakan korelasi Rank Spearman, dengan cara mengkorelasikan setiap variabel independen dengan varian gangguan (residual). Apabila nilai sig. (2-tailed test) $<0.05$ maka korelasi antara variabel independen dengan nilai residualnya dikatakan signifikan atau dengan kata lain ada gejala hetrokedastisitas. Sebaliknya apabila nilai sig. (2-tailed test) $>0.05$ maka korelasi antara variabel independen dengan residual dikatakan tidak signifikan atau data tersebut homokedastisitas. Dari hasil uji heterokedastisitas dengan menggunakan korelasi Rank Spearman, menunjukan bahwa tidak ada variabel independen yang berkolerasi signifikan terhadap nilai residual. Dengan demikian data yang digunakan data homokedastisitas.

\section{Tabel 4.4 Hasil Uji Heterokedastisitas}

\begin{tabular}{|c|r|c|}
\hline No & $\begin{array}{c}\text { Variabel } \\
\text { independen }\end{array}$ & Korelasi \\
\hline 1. & $\left(\mathrm{X}_{1}\right)$ &,- 037 \\
& Sig. (2-) &, 714 \\
\hline 2. & $\left(\mathrm{X}_{2}\right)$ &,- 104 \\
& Sig. (2-) &, 302 \\
\hline 3. & $\left(\mathrm{X}_{3}\right)$ &,- 031 \\
& Sig. (2-) &, 760 \\
\hline 4 & $\left(\mathrm{X}_{4}\right)$ &,- 086 \\
& Sig. (2-) &, 396 \\
\hline 5 & $\left(\mathrm{X}_{5}\right)$ &, 003 \\
& Sig. (2-) &, 976 \\
\hline
\end{tabular}

Sumber : Olah data penulis 2017

Untuk dapat menganalisis permasalahan tersebut digunakan analisis regresi linier berganda. Ringkasan hasil analisis dengan menggunakan program SPSS dapat dilihat dalam tabel berikut ini: 
Tabel 4.5. Hasil Analisis Regresi Linier Berganda

\begin{tabular}{|c|c|c|c|}
\hline No & $\begin{array}{l}\text { Valiabel } \\
\text { Independen }\end{array}$ & $\begin{array}{c}\text { Koefis } \\
\text { ien } \\
\text { Regres } \\
\text { i }\end{array}$ & Sig. $t$ \\
\hline 1 & $\left(X_{1}\right)$ & ,497 & ,000 \\
\hline 2 & $\left(\mathrm{X}_{2}\right)$ & ,348 & ,001 \\
\hline 3 & $\left(\mathrm{X}_{3}\right)$ & ,159 & ,047 \\
\hline 4 & $\left(\mathrm{X}_{4}\right)$ & 502 & ,000 \\
\hline 5 & $\left(\mathrm{X}_{5}\right)$ & 207 & ,004 \\
\hline \multicolumn{2}{|c|}{$\begin{array}{l}\text { Konstanta (Beta) } \\
, 849\end{array}$} & $=$ & Sig. F \\
\hline \multicolumn{2}{|c|}{ Multiple- $R$} & $=$ & \\
\hline \multicolumn{2}{|c|}{,940 } & & ... \\
\hline \multicolumn{2}{|c|}{$\begin{array}{l}\text { Adjusted R Square } \\
, 878\end{array}$} & $=$ & \\
\hline \multicolumn{2}{|c|}{$\begin{array}{l}\text { Durbin-Watson } \\
1.875\end{array}$} & $=$ & \\
\hline
\end{tabular}

Dari hasil analisis regresi linier berganda seperti dalam tabel di atas, kemudian dimasukkan ke dalam model persamaan regresi berganda sebagai berikut: $Y=0,849+0,497 \mathrm{X}_{1}+0,348 \mathrm{X}_{2}+0,159 \mathrm{X}_{3}$ $+0,502 \mathrm{X}_{4}+0,207 \mathrm{X}_{5}+\mathrm{e}$. Persamaan tersebut menunjukan, variabel independen yang dianalisis $\left(\mathrm{X}_{1}\right.$, $\mathrm{X}_{2}, \mathrm{X}_{3}, \mathrm{X}_{4}$ dan $\mathrm{X}_{5}$ ) berpengaruh positif terhadap nilai pertumbuhan GDP. Di mana, +e adalah yang menunjukkan standar error. Besarnya pengaruh variabel independen secara keseluruhan, ditunjukan oleh nilai koefisien Adjusted $R$ Square yaitu sebesar 0,878. Nilai tersebut dapat diartikan bahwa perubahan kelima pertumbuhan independen tersebut mempunyai pengaruh sebesar $87,8 \%$ terhadap variasi perubahan nilai loyalitas pertumbuhan GDP. Sedangkan sisanya sebesar 12,2\% dipengaruhi oleh variabel lain yang tidak dimasukkan dalam model (e). Sedangkan nilai koefisien korelasi (Multiple-R) yang diperoleh sebesar 0,940, hal tersebut dapat diartikan bahwa hubungan (korelasi) variabel independen $\left(X_{1}, X_{2}, X_{3}, X_{4}\right.$ dan $\left.X_{5}\right)$ terhadap variabel dependen (Y) adalah sebesar $94 \%$. Hipotesis pertama dalam penelitian ini adalah, variabel pertumbuhan GDP (X1-X5) secara serempak berpengaruh signifikan terhadap permalan pertumbuhan GDP. Untuk menguji apakah hipotesis pertama diterima atau ditolak digunakan uji F. Dari hasil pengujian diperoleh Sig F $0,000<\alpha=0.05$, ini berarti ke lima variabel yang diteliti X1-X5 secara serempak berpengaruh signifikan terhadap permalan pertumbuhan GDP. Dengan demikian hipotesis pertama yang diajukan dinyatakan diterima atau terbukti kebenarannya, dengan kata lain menerima hipotesis (H1) dan menolak hipotesis (Ho). Maka, hasil peramalan GDP adalah sebagai berikut:

Tabel 4.6. Peramalan GDP

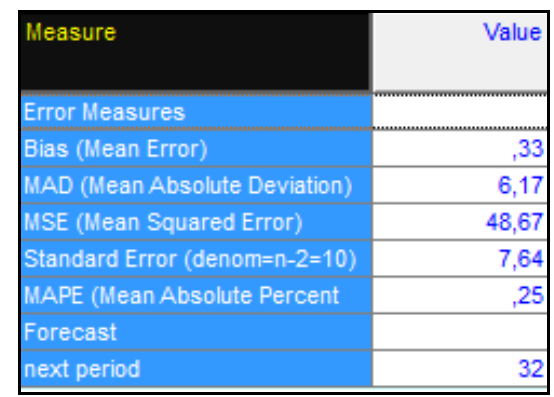

Sumber : Olah data penulis 2017

Terlihat analisa peramalan GDP dalam model naive methods akan menunjukkan nilai Bias atau mean error sebesar ,33. Sedangkan, nilai MSE adalah sebesar 48,67 yang mana merupakan Kesalahan 
Rata-rata Kuardrat (Mean Square Error), MSE merupakan cara ke dua untuk mengukur kesalahan peramalan keseluruhan. MSE merupakan rata- rata selisih kuardrat antara nilai yang diramalkan dan yang diamati. Kekurangan penggunaan MSE adalah bahwa ia cenderung menonjolkan deviasi yang besar karena adanya pengkuadratan. Nilai MAPE adalah sebesar 0,25 yaitu merupakan kesalahan persen Rata-rata Absolut (mean Absolute Percentage Error), MAPE dihitung sebagai rata-rata diferensiasi absolut antara nilai yang diramal dan aktual, dinyatakan sebagai persentase nilai aktual. Selanjutnya analisa berikutnya adalah dengan memperhatikan detail dan error analysis, yaitu didapatkan data forecast GDP untuk tahun berikutnya dengan data yang disajikan sebagai berikut:

Tabel 4.7 Peramalan GDP tahun berikutnya

\begin{tabular}{|c|c|c|c|c|c|c|}
\hline & $\begin{array}{l}\text { GGDP } \\
(Y)\end{array}$ & Forecast & Error & |Error| & Error $^{\wedge} 2$ & $\begin{array}{l}\mid \text { Pct } \\
\text { Error } \mid\end{array}$ \\
\hline $\mathrm{X} 1.1$ & 28 & & & & & \\
\hline $\mathrm{X} 1.2$ & 28 & 28 & -10 & 10 & 100 & .56 \\
\hline $\mathrm{X} 2.1$ & 20 & 18 & 2 & 2 & 4 & .1 \\
\hline $\mathrm{X} 2.2$ & 29 & 20 & 9 & 9 & 81 & .31 \\
\hline $\mathrm{X} 3.1$ & 35 & 29 & 6 & 6 & 36 & .17 \\
\hline X3.2 & 23 & 35 & -12 & 12 & 144 & .52 \\
\hline $\mathrm{X} 4.1$ & 31 & 23 & 8 & 8 & 64 & .26 \\
\hline $\mathrm{X} 4.2$ & 28 & 31 & -3 & 3 & 9 & .11 \\
\hline X5.1 & 20 & 28 & -8 & 8 & 64 & .4 \\
\hline $\mathrm{X} 5.2$ & 27 & 20 & 7 & 7 & 49 & .26 \\
\hline X5.3 & 29 & 27 & 2 & 2 & 4 & .07 \\
\hline X5.4 & 34 & 29 & 5 & 5 & 25 & .15 \\
\hline X6 & 32 & 34 & -2 & 2 & 4 & .06 \\
\hline TOTALS & 354 & & 4 & 74 & 584 & 2.96 \\
\hline AVERAGE & 27.23 & & ,33 & 6.17 & 48.67 & .25 \\
\hline \multirow{2}{*}{$\begin{array}{l}\text { Next Period } \\
\text { Forecast }\end{array}$} & & 32 & (Bias) & (MAD) & (MSE) & (MAPE) \\
\hline & & & & Std Err & 7.64 & \\
\hline
\end{tabular}

Sumber : Olah data penulis 2017

Telah didapatkan hasil forecast untuk tahun berikutnya dalam melakukan peramalan atas pertumbuhan GDP, yang mana Sehingga, tampilan antara permintaan dan peramalan, akan disajikan dalam grafik sebagai berikut.

Gambar 4.1. Siklus Pertumbuhan Peramalan GDP

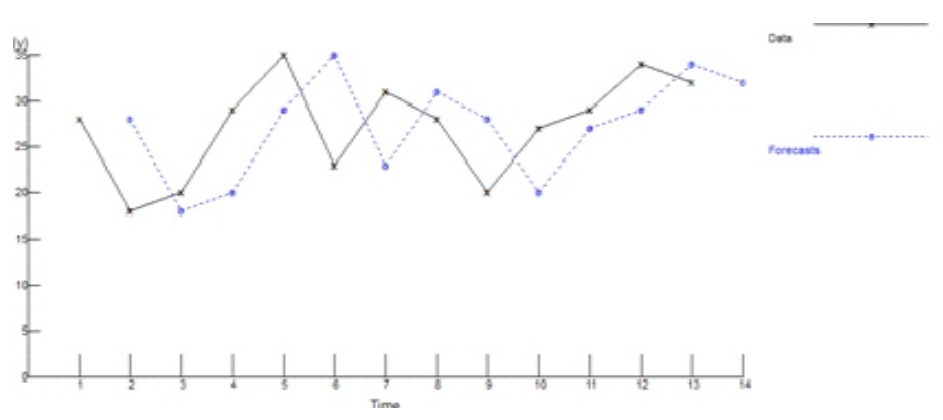

Sumber : Olah data penulis 2017

\section{Simpulan Dan Saran}

Hasil penelitian menunjukkan bahwa pertumbuhan GDP, dapat diramalkan berdasarkan perhitungan pertumbuhan yang telah terjadi di tahun sebelumnya. Dari hasil pengujian diperoleh Sig F $0,000<\alpha$ $=0.05$, ini berarti ke lima aspek pertumbuhan melalui pembiayaan yang diteliti secara serempak berpengaruh signifikan terhadap permalan pertumbuhan GDP. Beberapa elemen pertumbuhan GDP 
menunjukan signifikansi positif atas pertumbuhan dalam peramalan GDP. Dari hasil penelitian ini, kemudian penulis juga mendapati keterbatasan penelitian, di mana dalam mengukur GDP sebagai salah satu indikasi kesiapan masyarakat ekonomi dalam pasar ASEAN 2016 bisa dilaksanakan dengan detail-detail peningkatan secara ekonomi makro. Keterbatasan penelitiannya adalah bahwa penelitian ini hanya mengukur sebatas pembiyaan dalam masyarakat yang mempengaruhi GDP. Direkomendasikan sebagai saran dari penulis adalah bahwasannya dalam menciptakan suatu pengukuran atas GDP dalam menunjukkan kesiapan masyarakat dapat teridentifikasi melalui beberapa aspek, salah satunya adalah inflasi, kenaikan suku bunga dan beberapa aspek lainnya. Ketika semua terintegrasi, maka akan menghasilkan suatu nilai keakuratan dari peramalan.

\section{Daftar Pustaka}

Bureau of Economic Analysis, 2014. Corporate profits in the GDP accounts. BEA paper series, No. 0040. United States Department of Commerce, Economics and Statistics Administration, Bureau of Economic Analysis.

Chung, R.,Kryzanowski,L.,2012. Accuracy of consensus expectations for top-down earning spershare forecasts for two S\&P indexes. Applied Financial Economics 9 (3),233-238.

Croushore, D.D., 2011. Real-time forecasting. In: Higgins, MatthewL. (Ed.), Advancesin Economic Forecasting. W.E.Up john Institute for Employment Research. Kalamazoo:MI, pp.7-24.

Fischer, S., Merton, R.C., 1984. Macroeconomics and finance: the role of the stock market. NBER working paper series, No. 1291. NBER: Cambridge, MA.

Hann, R.N., Ogneva, M., Sapriza, H., 2012. Forecasting the macroeconomy: analysts versus economists. NBER: Cambridge, MA

Kaplan, Robert M. and Saccuzo, Dennis. 2003. Psychological Testing, Principles, Applcations, and Issues, Brool/Cole Publishing Company, a division of Wadsworth, Inc.

Konchitchki,Y., 2011. Inflation and nominal financial reporting :implications for performance and stock prices. Journal of Accounting Review86 (3),1045-1085.

Nasution, Mulia. 2008. Ekonomi Moneter, Uang dan Bank. Jakarta: Djambatan.

Rangkuti, Freddy. 2007. Riset Pemasaran Cetakan Pertama. Jakarta: PT. Gramedia Pustaka Utama.

Solimun. 2002. Multivariate Analysis Structural Equation Modelling (SEM), Lisrel dan Amos: Aplikasi di Manajemen, Ekonomi Pembangunan, Psikologi, Sosial, Kedokteran dan Agrokompleks. Malang: Pusat Dokumentasi Ilmiah Universitas Negeri Malang.

White, H.,1980. A heteroskedasticity- consistent covarian cematrix estimator and a directtest for heteroskedasticity. Econometrica 48(4),817-838.

Zarnowitz, V., Braun P., 2013. Twenty-two years of the NBER-ASA quarterly economic outlook surveys: aspects and comparisons of forecasting performance. Business Cycles, Indicators, and Forecasting, James Stock and Mark Watson, eds. Chicago: The University of Chicago Press 